\title{
MEEDIAUUDISTE AGENT
}

\author{
Reet Kasik \\ Tartu ülikool
}

Lähivertailuja 17.

Toimittaneet Annekatrin Kaivapalu, Külvi Pruuli.

Jyväskylä Studies in Humanities, 53.

Jyväskylä: Jyväskylän yliopisto, 2006, pp. 155-165.

ISBN 951-39-2450-5

ISSN 1459-4323 


\section{Funktsionaalne tekstianalüüs}

Ajakirjanduse mõjujõud on oma olemuselt keeleline. Ajakirjandus ei ole füüsiliselt mitte midagi muud kui tekst ja tema mõju põhineb sellel, missugune see tekst on. Elamine tänapäeva maailmas vastutusvõimelise kodanikuna eeldab, et inimene oskab seda keelt kriitiliselt lugeda. Ei piisa tähelepanu pööramisest üksnes sisule, käsitletavatele teemadele. Niisama oluline on ka vaadelda, kuidas tekst on üles ehitatud, miks see on niisugusena kavandatud ja mil viisil seda oleks võinud teisiti teha.

Funktsionaalne lingvistika (vt nt Halliday 1994) rõhutab asjaolu, et kõik tekstid põhinevad keelelistel valikutel ja valikud loovad tähendusi. Valik on alati tehtud mingil põhjusel, teatud väljendusviisil on mingi eesmärk ja valikud oleks võinud põhimõtteliselt olla ka teistsugused. Variantide hulk, mis teksti autoril kasutada on ja mille hulgast praktiliselt valik tehakse, on suur - kogu keelesüsteem ja olemasolev sõnavara. Sotsioloogiliselt ja kultuurilooliselt pakub huvi, mis määrab iga konkreetse valiku. Lugematu arv kultuuri ja meedia uurijaid on 1990-ndatel aastatel keskendunud nende seoste selgitamisele, mil viisil ühiskondlikud ja kultuurilised tingimused kujundavad diskursiivseid harjumusi (s.t. teatud kindlat tüüpi valikuid) ja mil viisil teksti valikud omakorda kujundavad ühiskondlikke ja kultuurilisi tingimusi (vt nt Fairclough 1992, 1995). Tavad muutuvad aja jooksul: esitusviisid võiksid olla teistsugused, nad on olnud teistsugused ja muutuvad edaspidigi. Uurimissuunda, mis peab oluliseks nimetatud küsimusi, tuntakse kriitilise diskursuseanalüüsi nime all. Tähelepanu all on eeskätt avalik ja institutsionaalne keelekasutus. Jälgitakse, milliseid valikuid kuskil registris (näiteks meedias) tehakse ning kuidas ja milliseid tähendusi sel teel kujundatakse.

Muude tunnuste hulgas on tähenduse loomisel oluline, mis on tekstis esindatud, mis on kõrvale jäetud; mis on primaarne (fokuseeritud), mis aga jäetud tagaplaanile; missugused protsessid ja tegevused on tekstis esindatud, mis tüüpi on nendes protsessides osalejad; kuidas osalisi nimetatakse; kuidas protsessid ja osalised on kategoriseeritud ja kuidas neid kirjeldatakse. 


\section{Uudisteksti tunnusjooni}

Siinses artiklis vaatlen uudistes representeeritavaid protsesse ja protsessiosalisi, kitsamalt seda, kuidas meediauudistes väljendatakse tegijat. Meediauurijad on tähele pannud, et agendi roll meedias on taandunud ja muutunud. Käsitlen oma artiklis selle muutuse olemust ja põhjusi ning vaatlen agendi representeerimise viise trükiajakirjanduses. Näitelaused on 2003. aasta Postimehest. Võrdluseks kasutatavate varasemate aastate kvantitatiivsed andmed pärinevad Tartu Ülikoolis 2004. aasta kevadel valminud Kerli Tennosaare bakalaureusetööst “Tegevused ja protsessid ajaleheuudistes 1983 - 2003" (juhendaja Reet Kasik). Uurimus on osa Eesti Teadusfondi toetusel Tartu ülikooli eesti keele ôppetoolis tehtavast teadusprojektist "Meediatekstide keelekasutus ja selle sotsiaal-kultuurilised taustad".

Ajakirjanduse uurijad vaatlevad ajakirjandust paljudest eri aspektidest. Austini ülikooli filosoofiaprofessor Douglas Kellner on oma 1995. aastal ilmunud raamatus "Meediakultuur" nimetanud meediakultuuri ühiskondliku võimuvõitluse areeniks. Ta juhib tähelepanu, et ajakirjandus kujundab ja tõlgendab poliitilist ja majanduslikku käitumist, avalikku arvamust ja hinnanguid (Kellner 1998: 47). Selle formuleeringu järgi on poliitiline ja majanduslik käitumine nähtus, mida iseloomustab liigitav täiend (käitumine võib olla majanduslik või poliitiline), sel käitumisel ei ole aga väljendatud agenti (kes käitub). Viited käitumisele loovad vähemalt argimõtlemise tasandil pildi inimestest ja tegutsejatest; ka muud refereeritud lauses nimetatud protsessid - kujundamine, tõlgendamine, arvamine ja hindamine - on nimelt inimestele ja inimliigile tüüpilised vaimsed tegevused. Aga inimest ennast selles tekstis ei ole. Analoogilisest nähtusest on majandustekstide põhjal kirjutanud Pirjo Karvonen (1997: 151-167.) Eesti keeles on sellist väljendusviisi ja nominaliseeritud verbivormide tekstitähendusi hiljaaegu lähemalt analüüsinud Krista Kerge (2003). Kerge analüüs on leksikaalse vaatepunktiga: ta ei vaatle mine-tuletisi ainult nominalisatsioonina, s.t. protsessi inkongruentse väljendusena, kust protsessi osalised on taandatud. Kerge on pööranud suurt tähelepanu protsessinimetuste idiomatiseerumisele - neid kasutatakse üha rohkem abstraktsete sündmuste või nähtuste nimetustena, mitte predikaatnominalisatsioonina (termini kohta vt Kasik 1975), mille puhul eeldaks protsessis osalejaid ja tingimusi. Selline protsesside transformeerimine nähtusteks ja mõisteteks ning mõistete omavaheliste suhete esitamine on omane analüütilisele tekstile, mida Kerge uurimustes esindab teadustekst ja kuhu kuulub ka Kellneri ülal analüüsitud näide. Teadusteksti potentsiaalsed lugejad on intellektuaalid, kellelt eeldatakse vastavat mõistmise tasandit.

Meediaväljaanded on mõeldud massilugejale ja mõistetasandi arutlused on siin enamasti kohatud. Kognitiivsete tekstitüüpide (vt nt Werlich 1982) skaalal on meediale iseloomulikud kaks tekstitüüpi: arvamuskirjutised, kolumnid, retsensioonid jm hinnangut sisaldavad tekstid kuuluvad argumenteeriva tekstitüübi alla, uudiste puhul räägitakse enamasti narratiivsest tekstist (van Dijk 
1988; Bolivar 2002; Heikkinen 1999: 150-211). Uudiseid ja arvamuskirjutisi ühendavaks ja teineteisele lähendavaks lüliks võib pidada tänapäeval üha tavalisemaks muutuvaid arvamusuudiseid: meediaväljaanded võistlevad omavahel, kes saab kedagi esimesena või mingist uuest vaatepunktist mingit asja kommenteerima (Heikkinen 1999: 191; Kasik 2002).

Siinse artikli uurimismaterjaliks on uudised: kodu- ja välissõnumid; poliitikat, ühiskondlikke küsimusi, teadust jne. käsitlevad artiklid, reportaažid ja ülevaated. Arvamuskirjutised kui täiesti teistsuguse tekstitüübi olen praegu kõrvale jätnud. Vaatlen siis eeskätt uudiste lauseis predikaatverbiga kirjeldatavaid protsesse ja jälgin, milliste tunnustega on neis protsessides osalejad. Klassikaliselt eeldatakse ajalehe uudissõnumilt vastuseid kuuele põhiküsimustele: kes, kus, millal, mida, kuidas ja miks tegi ( Peegel 1970: 125; vt ka Fairclough 1989: 137-138). Olen oma varasemates uurimustes (vt nt Kasik 2002) juhtinud tähelepanu sellele, et sellisele klassikalisele uudiste funktsionaalsele skeemile vastavad tänapäeva Eesti lehtedes veel üksnes sõnumid õnnetustest ja kuritegudest.

Neli purjus ajateenijat võtsid ööl vastu pühapäeva Lääne-Virumaal Tapal asuvast sõjaväeosast omavoliliselt veoauto ja rammisid sellega Ambla asulas elumaja

Ukraina päritolu 27-aastane mees tappis Californias oma raseda naise, sõitis seejärel teise Sacramento eeslinna ja tappis seal veel neli inimest ning põgenes siis koos oma kolmeaastase pojaga

Sageli on ka sellistes sõnumites representeeritud mitte tegu (Kes mida tegi?), vaid sündmus (Mis juhtus? Milline on olukord?)

Veretöö leidis aset Sacramento Nord Islands'i eeslinnas esmaspäeva hommikul

Loomakaitsjate ajanappus jätab õnnetud loomad kaitseta

Valdav enamik tänapäeva Eesti uudissõnumitest on tekstid tekstidest: mida keegi kuskil ütles ja mida teised selle peale ütlesid.

EKEB peaekspert Marika Väli ütles Postimehele, et purjus juhtide joobeekspertiiside tegemisel ei saa viimane sõna jääda ükskõik kui täpsele politsei möötevahendile, vaid inimesel peab olema alati õigus lasta teha vereanalüüs

2002. aasta analüüsitulemuste järgi nimetas kõigist analüüsitud lauseist teate allikat kas otse (NN ütles et...) või nominaliseeritult ( $N N-i$ sõnul) Postimehes 45,4 protsenti ja Eesti Päevalehes 36,2 protsenti lauseist. Kui võtta arvesse ka rinnastatud pealaused, siis väljendab verbaalset tegevust 37,6 protsenti Postimehe ja 33,3 protsenti Eesti Päevalehe pealausete predikaatidest (Kasik 2002: 206-207). ${ }^{1}$

Tegelikult on laenatud teksti osa veel suurem, sest saatelauseta, vormiliselt sõltumatud tsitaadid on kvantitatiivses analüüsis loetud iseseisvateks (pea)lauseteks. 


\section{$3 \quad$ Protsessid ja ja tegijad}

Kui vaadata protsesside liike ja osalisi ajakirjanduse uudistekstide lausetes aastakümnete lõikes, siis üksikisikute representeerimine tegijana ajaleheuudistes on näidanud selget tõusu. Kvantitatiivsed andmed pole eespool viidatud uudiste süntaksi uurimusega (Kasik 2002) täpselt võrreldavad, kuna lauseid loeti erinevalt. Ka on siin kasutatavate andmete hulgast praegu täiesti kõrvale jäetud seisundilaused, s.t. vaatlen ainult tegevus- ja toimumisprotsesside representeerimist. Võrdlusandmed põhinevad ajalehe Postimees (PM, 1983. aastal ilmus Edasi nime all) ühe numbri kõigi uudiste analüüsil 1983, 1993 ja 2003. aastal (vt Tennosaar 2004). Vaatluse all on siis väljenduse muutumine ühes ajalehes aastakümnete lõikes. Võrreldavaid lauseid oli 1983. aastal 359, 1993. aastal 399 ja 2003. aastal 397, seega on arvud üsna hästi kõrvutatavad. Järgnevas analüüsis on eristatud individualiseeritud agendiga protsessid (Peaminister Andrus Ansip kinnitas, et...), kollektiivse agendiga protsessid (Juhatus otsustas, et...), eksplitsiitse agendita impersonaalsed protsessid (Ö̈̈ jooksul murti sisse kahte autosse), elutu, s.t. metafoorse agendiga tegevused (Valimiseelne olukord mõjutab poliitikute otsuseid) ning agendita, nn automaatsed toimumisprotsessid (Mered saastuvad üha kiiremini).

TABEL 1 Tegevus- ja toimumisverbide agent uudistekstides 1983-2003 (\%)

\begin{tabular}{|l|l|l|l|l|l|l|}
\hline Aasta & Lauseid & Isik & Kollektiiv & Imperson. & Metafoorne & Agendita \\
\hline & & & & & & \\
\hline 1983 & 310 & 14,7 & 33,4 & 27,9 & 8 & 15 \\
\hline 1993 & 361 & 21.8 & 36 & 22,3 & 9,5 & 11 \\
\hline 2003 & 360 & 29,5 & 33,3 & 14,4 & 12,7 & 9,3 \\
\hline & & & & & & \\
\hline
\end{tabular}

1983.a. Edasis oli tegevus- ja toimumisverbidega lauseid 359st 310, neist tegijaks üksikisik 14,7 \% lausetest. 1993.a. Postimehes oli tegevusverbiga lauseid 399st 361, neist üksikisiku tegevusi 21,8 \%, 2003.a. Postimehes oli tegevuslauseid 397st 360, sealhulgas üksikisiku tegevusi juba 29,5. Üksikisikud esinevad siis lehes agendina järjest sagedamini. Kui vaadata lähemalt tegevusliike, milles nood representeeritud üksikisikud osalevad, siis tuleb selgesti välja, et üksikisiku põhitegevus ajaleheuudistes on ja on ikka olnud rääkimine: kõigist üksikisiku tegevustest uudistes moodustab rääkimine 1983 a Edasis 57,7\%, 1993 a Postimehes $67,7 \%$ ja 2003 a Postimehes 52,6\%

TABEL 2 Üksikisik agendina eri protsessitüüpides uudistekstides 1983-2003 (\%)

\begin{tabular}{|l|l|l|l|}
\hline Protsessitüüp & E1983 & PM1993 & PM2003 \\
\hline Verbaalne & & & \\
\hline Materiaalne & 57,7 & 67,7 & 52,6 \\
\hline Mentaalne & 32,6 & 24 & 35,1 \\
\hline
\end{tabular}


Esimesest tabelist on näha, et üksikisikust sagedamini on tegevuslausete agent kollektiveeritud. See võib olla institutsioon nagu valitsus, metonüümne kohanimi nagu Eesti, hulgasõna nagu rahvas, grammatiline mitmus nagu ministrid, loetelu, mitmuslik pronoomen või kvantifitseeritud hulk.

Valitsus andis loa sõlmida üürileping...

Eesti kaotab oma peamise konkurentsieelise....

Saksamaa hoiatas EL-i praegusi ja tulevasi liikmeid...

Eesti rahvas võttis rahvahääletusel vastu EV põhiseaduse täiendamsie seaduse...

Politseinikud alustasid uuesti otsinguid...

Austria, Tšehhi, Soome, Ungari, Leedu, Malta ja Sloveenia peaminister saatsid...

“...me peame inimesi seoses uute masinatega ümber paigutama..."

800st töötajast kaotab koha umbes sada

Kollektiivne tegija esineb uudistes kõige sagedamini ja läbi aastakümnete üsna stabiilselt: 1983 a 33,4\%, 1993.a. 36\% ja 2003 a 33,3 \%. Tegevusliike võrreldes saab selgeks tööjaotus: üksikisikud räägivad, massid tegutsevad: kõigis analüüsitud lehenumbrites on kollektiivse osalise puhul esikohal materiaalne tegevus.

TABEL 3 Kollektiiv agendina eri protsessitüüpides uudistekstides 1983-2003

\begin{tabular}{|l|l|l|l|}
\hline Protsessitüüp & E1983 & PM1993 & PM2003 \\
\hline Materiaalne & & & \\
\hline Mentaalne & 69,2 & 71,7 & 69,5 \\
\hline Verbaalne & 26,3 & 14,1 & 13 \\
\hline
\end{tabular}

1983 a uudiste erinevus kollektiivset tegijat silmas pidades on mentaalsete protsesside rohkus ja verbaalsete vähesus. Kuigi vastav kvalitatiivne analüüs on alles pooleli, on subjektiivsete tähelepanekute järgi nõukogude ajale iseloomulik viidata kollektiividele abstraktselt ja emotsionaalselt (rahvas tahab, partei mõtleb rahvale jne). 1993. ja 2003. a uudiseid iseloomustab kollektiivide verbaalsete tegevuste representeerimise kasvav osakaal ( Brüssel nõuab, Valitsus kinnitab, et...). Mentaalsete ja verbaalsete protsesside vahel pole ka alati võimalik kindlat piirjoont tõmmata, sest oma soove, mõtteid, tundeid võib ka sõnaliselt väljendada (vrd Kõneleja rõomustas, et...).

Umbisikulisus on uudistes aastakümnete jooksul vähenenud. Kui 1983.a. oli impersonaali 27.9 \% lausetest, siis 1993.a. 22,3\% ja 2003,a, vaid $14,4 \%$. Umbisikulisuse on asendanud üksikisikud, kelle protsent on vastavalt umbisikulisuse vähenemisele samavõrra tõusnud. 
Nagu tabelist näha, kasutatakse impersonaali tegelikult kahel esineval viisil. Ühel juhul on tegija uudises eespool mainitud ning teises lauses pole põhjust või ei taheta teda korrata ja asendatakse impersonaalivormiga:

Tuukrid asusid juba eile hommikul tiiki läbi otsisima. Õhtuks pumbati tiik täielikult veest tühjaks ja kombati põhjamuda rehadega, kuid Andresest ei leitud märkigi.

Sellist tekstitegemisviisi nimetatakse tegija taustalejätuks. Väljajätuga on tegemist siis, kui tegija pole tekstist välja loetav:

Kambja vallas murti sisse poodi ja varastati nahkjopp.

Olen impersonaali hulka lugenud ka sisult umbisikulised, s.t. agendita deontilise modaalsuse (kellegi nimetamata osalise käskimise, suunamise) juhud:

Jätkuva konkurentsivõime ja edasise arengu tagamiseks tuleb töö efektiivsust veelgi suurendada ning jätkata investeeringuid uutesse tehnoloogiatesse.

Agendi taustalejätu ja väljajätu võrdlemine eri aastakümnetel viitab samuti tegija rolli suurenemisele uudistekstides: agendi väljajätt on vähenenud, agendi taustalejätt umbisikulise tegumoe abil pole aga tegelikult märk teksti impersonaalsusest, vaid pigem tekstimoodustusviisist.

TABEL 4 Impersonaalne agent uudistekstides 1983-2003 (\%)

\begin{tabular}{|l|l|l|l|}
\hline & E1983 & PM1993 & PM2003 \\
\hline & & & \\
\hline Taustalejätt & 35,8 & 48,3 & 53,4 \\
\hline Väljajätt & 64,2 & 51,7 & 46,6 \\
\hline
\end{tabular}

Tegevusverbid eeldavad üldjuhul tegijaks inimest, aga see isik pole lauses alati esitatud subjektina, vaid võib jääda tagaplaanile või varjatuks. Vormiliseks subjektiks on lauses sel juhul mingi muu nähtus, abstraktsioon või objekt, nn metafoorne agent. Tekstiuurijad on sellisele tekstimoodustusviisile kui agendi varjamise vahendile korduvalt viidanud (vt nt Fairclough 1997: 39-41). Ka Tiit Hennoste on "Uudiste käsiraamatus" juhtinud tähelepanu, et laused nagu Kaubaautod sõidavad liiga kiiresti hämardavad põhjussuhteid, jättes mulje, et tegu on millegi objektiivsega, vääramatu loodusjõuga. Kui abstraktne nähtus on lauses tegijaks, siis taoliselt esitatud lause taga on siiski vastutavaks inimene, kuid mingil põhjusel pole tema isikut tahetud või peetud vajalikuks representeerida. Muidugi võib isik ka teadmata olla, aga metafoorse agendiga isegi ei viidata, et kuskil on paratamatult olemas ka protsessiga seotud inimene või inimesed. Sellisel juhul tekib vägisi kahtlus, et tegija representeerimine või representeerimata jätmine on ideoloogiline valik. Puhtstatistiliselt näib metarfoorse agendi osa mõnevõrra suurenenud: 1983.a uudistes oli selliseid lauseid 8\%, 1993. aasta uudistes veidi alla 10\% ja 2003 a uudistes ligi 13\%. Tõsi küll, siin puudub impersonaali kasutamisega võrreldav analüüs selle kohta, kui sageli on tegemist 
agendi taustalejätuga (s.t agent on mujal tekstis siiski nimetatud), kui sageli väljajätuga.

Agendi positsioonis võib olla inimese tegevust või sellest tulenevat olukorda kirjeldav nimisõna:

See poliitika hakkaks mõjutama poole miljardi inimese elu

Uute tehnoloogiate kasutuselevõtmine sunnib Eesti ettevõtjaid töötajaid koondama

Kulude kärpimine toob kaasa koondamised

Politseimaja rentimine neelab üle 58 miljoni

Kohustuslik sissekirjutus võiks parandada maksude laekumist

Kokkuhoid puudutas ka USA saatkondade informatsiooniprogrammi

Senised katsed islamimaailma mõjutada on andnud tagasihoidlikke tulemusi

Iisraeli turvatara ei peata rünnakuid

Üks võimalus tegija representeerimata jätmiseks on ka pasiivsete või automatiivsete toimumisverbide kasutamine aktiivsete tegevusverbide asemel. "Uudise käsiraamatu" autor Tiit Hennoste (2001) on nimetanud seda grammatiliste vahendite abil manipuleerimiseks. Protsessiverbide kasutamine on hea võimalus tegijat peita ja jätab mulje, et sündmus toimus iseenesest, nagu loodusseaduste mõjul: loodus saastub, rahvas jääb vaesemaks, valitsus kukub, hinnad tõusevad (vt ka Kasik 2001: 14-20.) 1983. aasta uudistekstides väljendas iseeneslikke protsesse $15 \%$ kõigist lausetest, 1993. aastal 11\% ja 2003. aastal 9,3\%:

Ühendriikide maine on langenud

Ameerika-vastane hoiak on jõudnud šokeerivale tasemele

Hakkas laekuma kaebusi

Staadion ei saa tänavu päris valmis

Kampaania sai alguse paar aastat tagasi

Tema kuupalgaks saab 250000 krooni

Kallasest sai üks euroliidu juhtivatest figuuridest

Eesti firmasid tabas septembris koondamine

Erastamisele eelneb riigi omandi munitsipaliseerimine

Odav tööjõud kaob.

Muidugi on olemas ka selliseid looduslikke protsesse, mis toimuvadki ilma inimese sekkumiseta (ilmad lähevad külmaks, lennuk kukkus alla, müür variseb kok$k u)$. Meediauudistes representeeritud iseeneslike protsesside taga on aga peaaegu alati inimene, kes on jäetud taustale või üldse uudistest välja. Sageli on 
subjekti positsioonis nominaliseeritud deverbaal ja protsessiverb on suhteliselt tühja tähendusega (toimub erastamine).

Tekstiuurijad on pannud tähele, et iseeneslikke protsesse esineb eriti sageli keskkonna- ja majandustekstides, kus asjad muudest valdkondadest hõlpsamini paistavad toimuvat iseenesest. Protsessiverbide laieneva kasutuse taga on kogu maailmas täheldatav ametliku keele bürokratiseerumine: kalduvus eelistada anonüümset, ebakonkreetset, ümardatud väljendusviisi. Selle tendentsi üks ilmnemisvorm on ka passiivi eelistamine aktiivivormile. Selle suunitluse taustal moodustavad uudistekstid teistsuguste tunnustega tekstiliigi. Ka Eesti päevalehtede uudistekstide süntaksi muutumise suund on vastupidine: nii impersonaali kui ka iseeneslike protsessiverbide hulk eri aastakümnetel on vähenenud (mis on ju kena), aga nad on vähenenud üksikisiku verbaalse tegevuse kasuks: ajakirjanike kirjutatud ülevaateid sündmustest on uudistekstides üha vähem, üha rohkem pööratakse tähelepanu sellele, kes mida ütles ja mida teised selle peale ütlesid.ning üha suurem osa uudistest kujutab endast allikaviidetega varustatud tsitaate ja refereeringuid

Avaliku meedia võimukasutuse vaatepunktist on edasises analüüsis oluline pöörata tähelepanu siinses artiklis väljatoodud rühmade koostumusele ja detailsemale vaatlusele: kes on need üksikisikud, kes saavad oma seisukohta esitada ja milliste protsessidega seoses; kes ja milliste protsessidega seoses esinevad konkreetsemalt või abstraktsemalt iseloomustatud rühmana või peituvad impersonaalsete vormide varjus. 


\section{KIRJANDUS}

Bolivar, A. 2002. The structure of newspapers editorials. Advances in written text analysis. London: Routledge. 276-294.

van Dijk, T. A. 1988. News as discourse. New Jersey: Lawrence Erlbaum Associates Inc.

Fairclough, N. 1989. Language and Power. London: Longman.

Fairclough, N. 1992. Discourse and Social Change. Cambridge: Polity Press.

Fairclough, N. 1995. Media Discourse. London: Edward Arnold.

Fairclough, N. 1997 (1995). Miten media puhuu. Tampere: Vastapaino.

Halliday, M.A.K. 1994. An introduction to functional grammar. Baltimore: Edward Arnold.

Heikkinen, V. 1999. Ideologinen merkitys kriittisen tekstintutkimuksen teoriassa ja käytännössä. Helsinki: SKS.

Hennoste, T. 2001. Uudiste käsiraamat. Tartu: TÜ Kirjastus.

Karvonen, P. 1997. Missä on taloustekstin ihminen. Kieli 9. Teksti ja ideologia. Helsingin yliopiston suomen kielen laitos, 151-167.

Kasik, R. 1975. Verbide ja verbaalsubstantiivide tuletusvahekorrad tänapäeva eesti keeles. Keele modelleerimise probleeme V. Tartu: Tartu Riiklik Ülikool.

Kasik, R. 2001. Keel tekstidena. Oma Keel 2002, 1, 14-20.

Kasik, R. 2002. Uudiste süntaks. Tähendusepüüdja. Catcher of the Meaning. Tartu ülikooli üldkeeleteaduse õppetooli toimetised 3. Tartu: TÜ Kirjastus. 200-219.

Kellner, D. 1998 (1995). Mediakulttuuri. Tampere: Vastapaino.

Kerge, K. 2003. Keele variatiivsus ja mine-tuletus allkeelte süntaktilise keerukuse tegurina. Tallinn: TPÜ Kirjastus.

Peegel, Juhan 1970. Ajalehežanrid. Ajaleht. Tartu: Tartu Riiklik Ülikool.

Tennosaar, K. 2004. Tegevused ja protsessid ajaleheuudistes 1983-2003. Bakalaureusetöö. (Juhendaja Reet Kasik). Käsikiri Tartu ülikooli eesti keele oppetoolis.

Werlich, E. 1982. Text grammar of english. Stuttgart: Quelle \& Mayer. 